Martin Nielsen*

\title{
The company brochure as a genre: Towards a textogram based on Danish and German brewery brochures
}

\section{Introduction}

Although contrastive analyses have been conducted on LSP genres, both intralinguistically and interlinguistically, quite a few genres and quite a few pairs of languages still remain to be scrutinized. For instance, a contrastive analysis af German and Danish LSP genres is still very much needed (Baumann \& Kalverkämper 1992: 25). Also, the genre 'company brochure' has only recently been an area of interest (Askehave 1998, Johansen 1999). Thus, a detailed linguistic description and comparison of Danish and German company brochures is a gap in interlingual LSP research which the $\mathrm{Ph} . \mathrm{D}$. thesis, which was defended on 17 March, 1999 and is summarized in the following, attempts to fill (Nielsen 1998/1999).

\section{Purpose and first methodological choices}

The purpose of the thesis is to construct a linguistic profile of the LSP genre 'company brochure' for Danish and German and then to compare those two profiles. The main structure of the method of analysis is

1. Intralingual analysis of texts in language $\mathrm{L}_{1}$

2. Intralingual analysis of texts in language $\mathrm{L}_{2}$

3. Interlingual analysis (i.e. comparison) of the results from 1 and 2

* Martin Nielsen

Tysk Institut

Handelshøjskolen i Arhus

Fuglesangs Allé 4

DK-8210 Arhus $V$ 
In continuation of that comparison, intercultural differences are pointed out, and finally some recommendations and suggestions for the translation of that genre between Danish and German are made.

A genre profile or textogram ${ }^{1}$ is a description of a genre on the basis of text-external and text-internal features. It is rougher and less differentiated than the more profound verbal description, which is the basis of the genre profile, but it submits a better overview of the genre in question since it is presented in a tabular form.

The approach of this thesis is characterized by being interdisciplinary (since various linguistic and non-linguistic disciplines contribute to the work), contrastive (the comparison is a major concern of the thesis), intercultural (cultural implications are investigated and discussed), semiotic (the sign nature of the texts is fundamental), textual/textlinguistic (the resulting genre profiles are textual units, not single phenomena), applicational (usefulness in translation/interculturalisation), linked up with a specific area (economics, marketing, brewing), and synchronic.

\section{The object of the analysis}

Although the thesis aims at a quite accurate description of the genre, which actually equals a (admittedly very profound) definition, a working definition to form the basis for the corpus selection is needed, since otherwise there would be no criteria for deciding if a given text could be included in a corpus of company brochures or not. As that definition I find Gelchsheimer appropriate:

\footnotetext{
"A company brochure ist a brochure which provides information about a company's line of business, size, products, history, employees, premises, location, etc. It represents image advertising and can be construed as a component of marketing [translation M.N.]" (Gelchsheimer 1991: 72).
}

\section{Corpus}

The corpus consists of 10 Danish and 22 German authentic company brochures from Danish and German breweries. In order to secure a certain homogeneity of the corpus, the corpus is limited to one branch, namely

1 From the German terms "Textsortenprofil" and "Textogramm" (Gläser 1992: 81). 
the brewing industry. Obviously the empirical findings will thus be valid specifically for brewery brochures and conclusions in respect of company brochures in general will have to be confirmed by further analyses.

\section{LSP field}

The texts are linked up with a specific area (economics, marketing ${ }^{2}$, brewing industry) in two different ways: Firstly the company brochure is a part of a company's communication and in that way an instrument that eventually serves financial interests, and secondly the very subject of the company brochure is the company itself, i.e. an economic unit is described and praised in the brochure.

The first perspective enables us to place the company brochure as a (communicative) instrument used by the company to contribute to achieving its longterm goals. In a simplified chain of a number of instrumental goals and one final goal you could say, that the longterm goal of every company is to maximize its profits (Wöhe 1993: 124). In order to achieve that, revenues must exceed spendings. In order to achieve that, you can either increase revenues or decrease spendings (or both). If you choose to increase revenues, you have several marketing instruments (the so-called four Ps: product, price, place, promotion, Kotler \& Bliemel 1995: 141-142). You could improve the product, increase prices, improve on distribution or strengthen communication efforts. If you choose to strengthen communication efforts you can go for promotion, personal selling, advertising or public relations. If you choose public relations you can issue press releases, make PR campaigns or produce a company brochure. Thus the company brochure can be looked upon as a PR instrument which eventually aims at higher profits.

The reason why it has become more and more important to increase revenues through communication instruments in the first place (and not

\footnotetext{
2 It turns out that the area with which the texts can be said to be linked up is the field of economics. Findings from most categories, particularly macro-structure, isotopy, and LSP characteristics, show that company brochures are rather economic LSP texts than technical LSP texts. Indications of economic LSP are found througout the texts while indications of technical LSP are almost entirely limited to certain textparts of a macrostructural lower hierarchical level, and according to Kalverkämper (1982: 149f.) the influence of linguistic features on a text is smaller the lower the level of macro-structure where those features are found.
} 


\section{8}

so much through other marketing instruments) is that products today are more or less technically developed and equivalent and functionally interchangable, so consumers expect and demand high technical and functional quality (Weinberg 1992: 64). Therefore the only way to differ from competitors' products is to describe and create an image of the producer (Pflaum \& Pieper 1993: 123). This then is where the company brochure comes in very handy.

\section{Model of analysis - methodological and theoretical considerations}

Hoffmanns (1987) approach of cumulative analysis is chosen as the starting point of the model of analysis. ${ }^{3}$ His model provides two very large hierarchically built matrices, one for text-internal and one for textexternal factors. Each matrix consists of several main categories (e.g. the text-internal of macro-structure, coherence, syntax, lexis, grammatical categories) which again are divided into subcategories (e.g. as for the grammatical category: verb, noun etc.) which again can be divided into smaller subcategories (e.g. for the verb subcategory: modus, genus, tempus, person, and the person again into 1., 2., and 3.) and so on.

The boundaries between the categories are not necessarily clear-cut, and Hoffmann's categories are highly heterogeneous. But the model is open for extensions at all category levels, which enables the analyst to alter it according to his needs. The text-external matrix is more a description of text-external facts than an analysis as such. The data for this matrix is rather provided by encyclopedic knowledge, trade surveys,

\footnotetext{
Originating from Weinrichs "Textpartitur" (1972) which was only a structural, i.e. a text-internal matrix with quantitative measurement (binary decision within the categories: does the phenomenon occur or not) and no possibility of qualitative statements, Hoffmann extended the structural matrix to comprising more and other categories and to emphasizing the importance of making statements not only about the occurrence but also about the frequency, distribution, and especially the meaning of the phenomena. He also included a text-external matrix which enriched the model significantly and has since demonstrated the model in use (Hoffmann 1995). For a more elaborate discussion of the model and a description of the history of its development see Nielsen (1998).

4 An actual placing of the genre in a genre typology I have disregarded since I tend to agree with Swales (1990) and Adamzik (1995) in "that genre analysis necessarily has something to do with constructing a classification of genres." (Swales 1990: 44), as opposed to Spillner (1981), Isenberg (1983), and partly Göpferich (1995).
} 
interviews with trade insiders, etc. than by analysis. The text-external factors explain why the specific text-internal factors are used. Vice versa, the text-internal factors are actual analyses, i.e. registration and interpretation of type, frequency, and distribution of text-internal phenomena. They are instrumental in relation to the text-external factors.

Thus a dialetic mode of analysis is pursued in that way that the (in principle theoretically investigable) text-external factors provide the explanation for the empirically investigable text-internal factors which in their turn support the theoretical assumptions about the text-external factors.

This model of analysis is exhaustive, but - or: therefore - it is not practibly possible to implement it fully. Therefore a selection from the vast amount of categories must be made. The criteria for this selection are firstly what critics may call intuition, but what may just as well be seen as text pattern or text genre competence; ${ }^{5}$ secondly the first superficial empirical findings, which give hints as to which categories might be relevant; thirdly the dialectical method, where text-external features found or presupposed point to text-internal features that are obvious to include in the text-internal matrix. In that way, "representatives" for each main category (e.g. isotopy for the semantic category, ellipsis for the syntactical, 1. person plural for the grammatical) are chosen and form the model of analysis.

\footnotetext{
5 A lot of other genre analysts, such as Lux (1981), Heinemann \& Viehweger (1991: 129), H. Oldenburg (1992: 47), and Göpferich (1995: 189), point out that they have to rely on their knowledge of text genre patterns and conventions when selecting the categories for analysing the respective LSP genres.
} 


\begin{tabular}{|l|}
\hline TEXT-EXTERNAL MATRIX \\
\hline Communication intention \\
\hline Communication object \\
\hline Sender \\
\hline Receiver \\
\hline Publication interval \\
\hline Distribution \\
\hline
\end{tabular}

\section{TEXT-INTERNAL MATRIX}

\section{Nonverbal}

Size

Format

Paper quality

Binding

Text-picture relation

Verbal

Macro-structure

Isotopy

LSP characteristics

Metacommunication and metalanguage

Intertextuality

Inclusion of sender

Inclusion of receiver

Ellipsis

\section{Main Results}

\subsection{Genre profiles - similarities and differences}

Based on the above-mentioned theoretical and methodological considerations, the following genre profiles have been worked out. The third column shows similarities and is a "neutral" profile of the brewery brochure. The second and the fourth columns show what is specific for 
the Danish an German brewery brochures respectively. In that way, the second and third columns illustrate the Danish profil and the third and the fourth columns the German. The table is only a summary of the real table, but it comprises the most important findings and shows the principle of the genre profile:

\begin{tabular}{|c|c|c|c|}
\hline $\begin{array}{l}\text { TEXT- } \\
\text { EXTERNAL }\end{array}$ & $\begin{array}{l}\text { Text-external features } \\
\text { and conditions of Danish } \\
\text { brewery brochures }\end{array}$ & 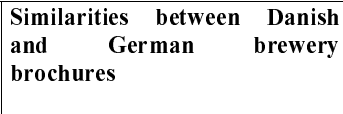 & $\begin{array}{l}\text { Text-external features } \\
\text { and conditions of } \\
\text { German r brewery } \\
\text { brochures }\end{array}$ \\
\hline $\begin{array}{l}\text { Communication } \\
\text { intention }\end{array}$ & Image profilation & Image profilation & $\begin{array}{l}\text { Image profilation and } \\
\text { increasing sale }\end{array}$ \\
\hline $\begin{array}{l}\text { Communication } \\
\text { object }\end{array}$ & Company & Company & Company and product \\
\hline Sender & Company & Company & Company \\
\hline Receiver & $\begin{array}{l}\text { Employees, investors, } \\
\text { suppliers, customers, national } \\
\text { population }\end{array}$ & $\begin{array}{l}\text { Public: market participants (e.g. } \\
\text { customers, suppliers, shareholders, } \\
\text { banks), institutions and } \\
\text { authorities/the administration (e.g. } \\
\text { the state, federation, unions), the } \\
\text { general public (neighbours, } \\
\text { interested people), employees } \\
\end{array}$ & 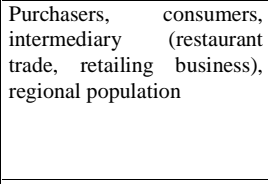 \\
\hline $\begin{array}{l}\text { Publication } \\
\text { interval }\end{array}$ & & Less than once a year & In one case once a year \\
\hline Distribution & $\begin{array}{l}\text { On demand, at company } \\
\text { visits }\end{array}$ & On demand & On demand \\
\hline
\end{tabular}




\begin{tabular}{|c|c|c|c|}
\hline $\begin{array}{l}\text { TEXT- } \\
\text { INTERNAL }\end{array}$ & & & \\
\hline \multicolumn{4}{|l|}{ Nonverbal } \\
\hline Size & $\begin{array}{l}\text { Small size occurs even in } \\
\text { major brewery groups }\end{array}$ & $\begin{array}{l}\text { Variation, } 14-19 \text { pages on average; } \\
\text { roughly good connection between } \\
\text { size and position of company and } \\
\text { number of pages; indexical sign for } \\
\text { financial potential }\end{array}$ & $\begin{array}{l}4 \text { and } 6 \text { page brochures } \\
\text { relatively frequent }\end{array}$ \\
\hline Format & None smaller than A5/A6 & $\begin{array}{l}\text { Variations occur; DIN A4 most } \\
\text { frequent format }\end{array}$ & Smaller formats occur \\
\hline Paper quality & $\begin{array}{l}70-170 \mathrm{~g} / \mathrm{m}^{2}, \text { average } 120- \\
150 \mathrm{~g} / \mathrm{m}^{2} ; \text { poor quality occurs }\end{array}$ & In general high quality; gloss & $\begin{array}{l}80-240 \mathrm{~g} / \mathrm{m}^{2}, \text { average } 120- \\
170 \mathrm{~g} / \mathrm{m}^{2} ; \text { only high quality, } \\
\text { no poor quality occurs }\end{array}$ \\
\hline Binding & Manual stapling occurs & $\begin{array}{l}\text { 12-24 pages: stapled; more pages: } \\
\text { glued or bound }\end{array}$ & $\begin{array}{l}4 \text { and } 6 \text { page brochures: } \\
\text { folded }\end{array}$ \\
\hline \multicolumn{4}{|l|}{$\begin{array}{l}\text { Pictures/text- } \\
\text { picture relation }\end{array}$} \\
\hline Size & $\begin{array}{l}\text { Double page to small (stamp } \\
\text { size) }\end{array}$ & Great variation & $\begin{array}{l}\text { Double centerfolds to small } \\
\text { (stamp size) }\end{array}$ \\
\hline Share & $\begin{array}{l}45.8 \%, \text { great variation, } \\
\text { extreme lowest }\end{array}$ & Generally quite high, variation & $\begin{array}{l}39.0 \%, \text { great variation, } \\
\text { extreme highest }\end{array}$ \\
\hline Colour & $\begin{array}{l}\text { Slight preference of green, } \\
\text { gold not represented }\end{array}$ & $\begin{array}{l}\text { Four colour print, high colour } \\
\text { quality }\end{array}$ & $\begin{array}{l}\text { Recognizable preference of } \\
\text { green; gold represented }\end{array}$ \\
\hline Type & $\begin{array}{l}\text { Logo rarely picture } \\
\text { dominating }\end{array}$ & $\begin{array}{l}\text { Photographies by far the most } \\
\text { frequent type of picture }\end{array}$ & Logo in prominent places \\
\hline Motive & $\begin{array}{l}\text { 1) persons 2) buildings 3) } \\
\text { machinery and equipment 4) } \\
\text { product 5) landscapes 6) } \\
\text { vehicles }\end{array}$ & $\begin{array}{l}\text { Persons (consumers, employees, } \\
\text { sponsorees), products, machinery } \\
\text { and equipment, buildings, } \\
\text { landscapes, vehicles, product } \\
\text { accessories }\end{array}$ & $\begin{array}{l}\text { 1) product 2) persons } 3 \text { ) } \\
\text { logo 4) reproduction of } \\
\text { certificates 5) landscapes } \\
\text { (often quite big) 6) vehicles } \\
\text { 7) product accessories }\end{array}$ \\
\hline Form & $\begin{array}{l}\text { quadrangular by far the most, } \\
\text { very few wihtout frames }\end{array}$ & $\begin{array}{l}\text { Clear majority of quadrangular, few } \\
\text { without frames }\end{array}$ & $\begin{array}{l}\text { Quadrangular clearly most, } \\
\text { few without frames }\end{array}$ \\
\hline $\begin{array}{l}\text { Text-picture } \\
\text { relation }\end{array}$ & & $\begin{array}{l}\text { As to information function: text } \\
\text { provides more information than the } \\
\text { picture (or the same) } \\
\text { As to appeal function: text provides } \\
\text { the same or less appeal than the } \\
\text { pictures }\end{array}$ & \\
\hline Function & & $\begin{array}{l}\text { Mainly appealing, always also } \\
\text { decorating and aesthetic, often } \\
\text { illustrative, rarely informative }\end{array}$ & \\
\hline
\end{tabular}




\begin{tabular}{|c|c|c|c|}
\hline $\begin{array}{l}\text { TEXT- } \\
\text { INTERNAL }\end{array}$ & & & \\
\hline Verbal & & & \\
\hline $\begin{array}{l}\text { Isotopy } \\
\text { denotative groups } \\
\text { Connotative } \\
\text { groups }\end{array}$ & $\begin{array}{l} \\
\text { [national] [international] } \\
\text { [efficiency] [market position] } \\
\text { [alcohol] }\end{array}$ & $\begin{array}{l}\text { [economics] [product] [production] } \\
\text { [method] [science \& technology] } \\
\text { [quality] [safety] [uniqueness] } \\
\text { [tradition] [geographic reference] } \\
\text { [success] [market position] }\end{array}$ & $\begin{array}{l}\text { [product] } \\
\text { [regional] [tradition] } \\
\text { [uniqueness] [safety] } \\
\text { [environment] [water] } \\
\text { [forest] [health] }\end{array}$ \\
\hline $\begin{array}{l}\text { Meta- } \\
\text { communication }\end{array}$ & $\begin{array}{l}\text { Quotations mostly from } \\
\text { company-internal persons or } \\
\text { texts; definitions, } \\
\text { explications and elaborations } \\
\text { more frequent }\end{array}$ & $\begin{array}{l}\text { In general not strongly represented; } \\
\text { often conventionalized quotation } \\
\text { marks; function: secure } \\
\text { understanding }\end{array}$ & $\begin{array}{l}\text { Quotations mostly from } \\
\text { company-external persons; } \\
\text { thematization of mental } \\
\text { actions }\end{array}$ \\
\hline $\begin{array}{l}\text { Inclusion of } \\
\text { receiver }\end{array}$ & $\begin{array}{l}\text { Personal pronouns, } \\
\text { imperative, exclamations are } \\
\text { sporadic; non-pronominal } \\
\text { mentioning of receiver are } \\
\text { rare and not very appealing }\end{array}$ & & $\begin{array}{l}\text { Personal pronouns, } \\
\text { imperative, exclamations } \\
\text { occur more often; non- } \\
\text { pronominal mentioning of } \\
\text { receiver are relatively } \\
\text { frequent and relatively } \\
\text { appealing }\end{array}$ \\
\hline Ellipsis & Mainly analepses & Elliptical enumerations & Mainly structural ellipses \\
\hline
\end{tabular}

\subsection{Attempt at cultural explanations}

On the basis of the above-mentioned genre profiles the thesis makes a few considerations in regard to possible cultural conclusions. Particularly one complex of alleged Danish national features is found confirmed, 
and that is the complex of modesty and egality, ${ }^{6}$ combined with the less well-known, but very fitting tribal behaviour and homogeneity. Previous studies ${ }^{7}$ and experiences ${ }^{8}$ have shown that Germany is a more conflicting culture while Denmark would be trying to avoid conflicts. Several empirical findings within different categories of analysis support this assumption:

In the Danish corpus, it is striking that in the macro-structure category only one part-text of first degree ${ }^{9}$ has the theme 'national market' opposed to five with the theme 'exports'. It is argued that a nation with such a pronounced tribal behaviour will try to avoid comparisons within the tribe, because that would be potentially conflict-evoking. Furthermore, the auto-stereotype of the janteloven might explain why the two biggest breweries in Denmark do not even mention, let alone use as a theme for a whole part-text, their common market share of 75 per cent of the Danish domestic market, namely not to reflect badly on their tribesmen.

While Danish egalitarism, envy, tribal consciousness, and understatement goes for internal affairs, because competition, hierarchical differences and success would be potentially consensus-threatening, that does not count for external comparisons: here it is legitimate to "brag" about international success.

Global isotopy chains featuring employees (and employees' working conditions and in-service training) occur four times in the Danish corpus

\footnotetext{
6 The so called Law of Jante (janteloven), some of whose rules are "Do not think you are important", "Do not think you are worth more than others", "Do not stand out from the majority", is the name for the phenomenon of envy and narrow-mindedness that is found in all cultures, but seems to be much more widespread in Denmark and only here has its own name since it has been manifested in literature by the novel "En flygtning krydser sit spor" (1933) by Aksel Sandemose about the small, fictional Danish town Jante.

7 In the power distance index of Hofstede 1993, which measures the readiness of a culture to engage in a conflict, Germany ranks much higher than Denmark.

8 According to Mellon 1992, Denmark is characterized by being very homogeneous because the nation has emerged from one tribe. Also he describes Danes as being very consensus-seeking.

9 The macro-structure of a text consists of several hierarchical levels the highest of which is the entire text (0th level), the second highest is a part-text of first degree, the third highest a part-text of second degree, and so on (Kalverkämper 1982: 117f.). Parttexts of first degree are among other things characterized by being linguistically and thematically relatively independent units and thus influencing on the entire text.
} 
and are supported by other isotopic chains on a lower level of macrostructure (regional and local isotopies); opposed to none in the German corpus. A reason for this might be that Denmark is less hierarchical than Germany, thus accentuating or at least mentioning the employees' role for the company while Germany as the more hierarchical culture to a certain extent ignores the hierarchically less important employees.

Furthermore, the slogan of Carlsberg "Probably the best beer in the world" contains a very clear hedging and finally the attribution of the lexeme "kvalitet" (quality) is usually "god" (good) and not more connotative adjectives like "fremragende" (excellent) or the like.

Accordingly, in the German corpus many linguistic features that suggest that the company or product is outstanding and exclusive, e.g. some of the German slogans ("Das einzig Wahre. Warsteiner", "Das König der Biere"), lexemes that give strong associations to uniqueness, exclusiveness, and noblesse ("edel", "premium") and other similar connotations found in global, regional, and local isotopic chains. ${ }^{10}$

A cultural dimension which is not taken into account by for instance Hofstede is the geographic reference unit. In the Danish corpus the nation and national virtues are used to create atmosphere and image; in the German corpus it is clearly the region and regional values. The fact that Denmark is more homogeneous, equal, and tribal might once more serve as an explanation. She also has a considerably longer national history, she became one state much earlier, and is centrally ruled; while Germany consists of many tribes (Saxons, Bavarians, Franks, Alemanni ...), was united as a nation or state much later, is more heterogeneous, has a federal structure, and is polycentral.

\subsection{Recommendations}

As a consequence of the empirical findings, the comparison of the genre profiles, and the cultural implications, a few recommendations for translating company brochures between Danish and German are made.

\footnotetext{
10 The concept of isotopy constructs chains of lexemes with recurrent dominating semantic properties. The thesis develops an approach where those isotopy chains are divided into three groups: global isotopy chains are spread throughout the entire text, regional isotopic chains are only found within part-texts of first degree, and local isotopy chains are limited to part-text of second degree or of a lower hierarchical level.
} 
Before that is done it is established that company brochures can in fact be translated between Danish and German and do not have to be rewritten from scratch by advertising agencies. General recommendations for translation brewery brochures:

- tactile and visual signs should not send contradictory signals and should be of proper quality

- company brochures should always be polysemiotic, i.e. contain both pictures and words

- when translating from German to Danish (unless a more documentary (Nord 1989, 1993) translation is chosen) the regional aspect should be toned down; nevertheless if by any chance national features should occur in German brochures, they should not be transferred since national values in a German context are not particuarly popular in Denmark

- German appellativity should be moderated in a Danish translation and vice versa: translations from Danish to German should take back their modesty and understatement and strengthen the appeal factor

- German exclusiveness should not be expressed so clearly in a Danish translation; Danish understatement and popular or even folksy mode of expression should be replaced by more emphasis on exclusiveness, noblesse and so on

\section{Research and application perspectives}

The thesis presented above is a small step towards a better description, explanation, understanding, and translation of one specific LSP genre. Further research would be desirable in various directions: First of all, larger surveys of the genre in question, comprising other lines of business, larger corpora and other and more languages would be of obvious interest. Also the translational recommendations I have given, and which were not the main purpose of the thesis, could very well give rise to more intensive studies in the shape of prescriptive rather than descriptive LSP genre analysis like it has been proposed by for instance Göpferich (1995) and Bolten et al. (1996). Furthermore, the intercultural dimension of the survey is a field that certainly deserves more interest. And finally, the virtual relative of the company brochure, the company website offers a wide field of research possibilities, from original text production, to 
research from an intergeneric point of view: how closely related are the company brochure and the company website, where are the similarities and where are the differences?

\section{References}

Adamzik, Kirsten (1995). Textsorten - Texttypologie. Eine kommentierte Bibliographie. Münster: Nodus.

Askehave, Inger (1998). A Functional Interpretation of Company Brochures - from context to text. Ph.D. thesis. The Aarhus School of Business.

Baumann, Klaus-Dieter \& Kalverkämper, Hartwig (eds.) (1992). Kontrastive Fachsprachenforschung. Tübingen: Narr.

Bolten, Jügen, Dathe, Marion, Kirchmeyer, Susanne, Roennau, Marc, Witchalls, Peter \& Ziebell-Drabo, Sabine (1996). Interkulturalität, Interlingualität und Standardisierung bei der Öffentlichkeitsarbeit von Unternehmen. Gezeigt an amerikanischen, britischen, deutschen, französischen und russischen Geschäftsberichten. In Baumann, Klaus-Dieter \& Kalverkämper, Hartwig (eds.) (1996). Fachliche Textsorten. Komponenten - Relationen - Strategien. Tübingen: Narr. 389-425.

Gläser, Rosemarie (1992). Methodische Konzepte für das Tertium comparationis in der Fachsprachenforschung - dargestellt an anglistischen und nordistischen Arbeiten. In Baumann, Klaus-Dieter \& Kalverkämper, Hartwig (eds.) (1992). Kontrastive Fachsprachenforschung. Tübingen: Narr. 78-92.

Göpferich, Susanne (1995). Textsorten in Naturwissenschaften und Technik. Pragmatische Typologie - Kontrastierung - Translation. Tübingen: Narr.

Heinemann, Wolfgang \& Viehweger, Dieter (1991). Textlinguistik. Eine Einführung. Tübingen: Niemeyer.

Hoffmann, Lothar (1987). Ein textlinguistischer Ansatz in der Fachsprachenforschung. In Sprissler, Manfred (ed.) (1987). Standpunkte der Fachsprachenforschung. Tübingen: Narr. 91-105.

Hoffmann, Lothar (1995). Intraserielle und interserielle Vergleiche von Fachtexten. Ein Beitrag zur Unterscheidung von Textsorten. In Popp, Heidrun (ed.) (1995). Deutsch als Fremdsprache: an den Quellen eines Faches. Festschrift für Gerhard Helbig zum 65. Geburtstag. Munich: Iudicum.

Hofstede, Geert (1993). Interkulturelle Zusammenarbeit. Kulturen - Organisationen Management. Wiesbaden: Gabler.

Isenberg, Horst (1983). Grundfragen der Texttypologie. In Daneš, František \& Viehweger, Dieter (eds.) (1983). Ebenen der Textstruktur. Berlin (East): xeroxed manuscript. 303-342. 
Johansen, Winni (1999). Kultursignaler i tekst og billede - kultur og kommunikation $i$ danske og franske proesentationsbrochurer. Ph.D. thesis. The Aarhus School of Business.

Kalverkämper, Hartwig (1982). Fachsprachen und Textsorten. In Høedt, Jørgen, Lundquist, Lita, Picht, Heribert \& Qvistgaard, Jaques (eds.) (1982): Pragmatics and LSP. Proceedings of the 3rd European Symposium on LSP Copenhagen August 1981. LSP Centre. Copenhagen Business School. 105-168.

Kotler, Philip \& Bliemel, Friedhelm (1995). Marketing-Management. Stuttgart: Schäfferpoeschel. 8th edition.

Lux, Friedhelm (1981). Text, Situation, Textsorte. Probleme der Textsortenanalyse, dargestellt am Beispiel der britischen Registeranalyse. Tübingen: Narr.

Mellon, Sir James (1992). Og gamle Danmark... En beskrivelse af Danmark $i$ det herrens år 1992. Copenhagen: Centrum.

Nielsen, Martin (1998). Hoffmanns kumulative tekstanalyse - metodisk stringens vs anvendelighed. In Netvark LSP Newsletter 13. 148-166.

Nielsen (1998/1999). Die Unternehmensbroschüre als Textsorte: Versuch eines Textogramms - dargestellt anhand von dänischen und deutschen Brauereibroschüren. Ph.D. thesis. The Aarhus School of Business.

Nord, Christiane (1989). Loyalität statt Treue. Vorschläge zu einer funktionalen Übersetzungstheorie. In Lebende Sprachen 3. 100-105.

Nord, Christiane (1993). Einführung in das funktionale Übersetzen. Tübingen/Basel: Francke.

Oldenburg, Hermann (1992). Angewandte Fachtextlinguistik. ,Conclusions ' und Zusammenfassungen. Tübingen: Narr.

Pflaum, Dieter \& Pieper, Wolfgang (eds.) (1993). Lexikon der Public Relations. Landsberg/Lech: moderne industrie. 2nd edition.

Spillner, Bernd (1981). Textsorten im Vergleich. Ansätze zu einer Kontrastiven Textologie. In Kühlwein, Wolfgang, Thome, Gisela \& Wilss, Wolfram: (eds.) (1981). Kontrastive Linguistik und Übersetzungswissenschaft: Akten des Internationalen Kolloquiums Trier/Saarbrücken 25.-30.09.1978. Munich: Fink. 239-250.

Swales, John M. (1990). Genre Analysis. English in Academic and Research Settings. Cambridge: Cambridge University Press.

Weinberg, Peter (1992): Erlebnismarketing. Munich: Vahlen.

Weinrich, Harald (1972). Thesen zur Textsorten-Linguistik. In Gülich, Elisabeth \& Raible, Wolfgang (eds.) (1972). Textsorten. Differenzierungskriterien aus linguistischer Sicht. Frankfurt/Main: Athenäum. 161-170.

Wöhe, Günter (1993). Einführung in die Allgemeine Betriebswirtschaftslehre. Munich: Vahlen. 18th edition. 